\title{
Erratum: The moderating role of career adaptability on the relationship between workplace spirituality and employee mental and physical health
}

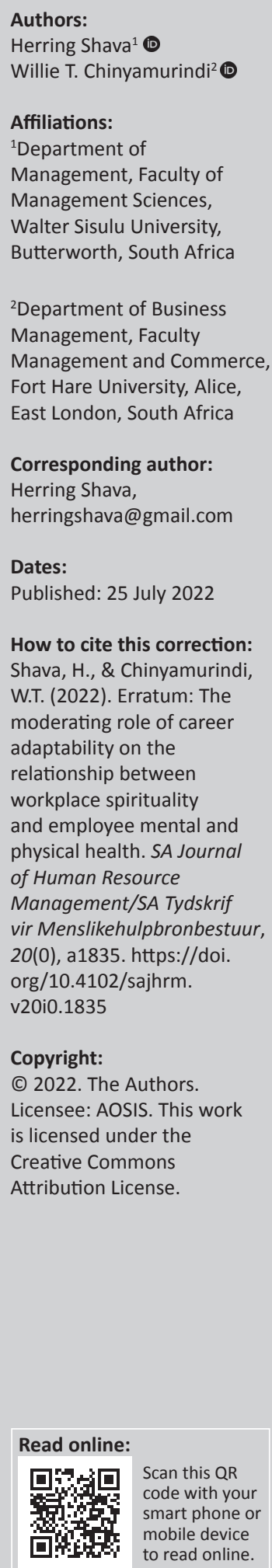

In the published article, Shava, H., \& Chinyamurindi, W.T. (2021). The moderating role of career adaptability on the relationship between workplace spirituality and employee mental and physical health. SA Journal of Human Resource Management/SA Tydskrif vir Menslikehulpbronbestuur, 19, a1437. https://doi.org/10.4102/sajhrm.v19i0.1437, there was an error regarding the affiliation for Herring Shava. Instead of 'Department of Business Management, Faculty Management and Commerce, Fort Hare University, Alice, East London, South Africa', it should be 'Department of Management, Faculty of Management Sciences, Walter Sisulu University, Butterworth, South Africa'. The publisher apologises for this error.

The correction does not change the significance of study's findings or overall interpretation of its results or the scientific conclusions in any way. 


\section{The moderating role of career adaptability on the relationship between workplace spirituality and employee mental and physical health}

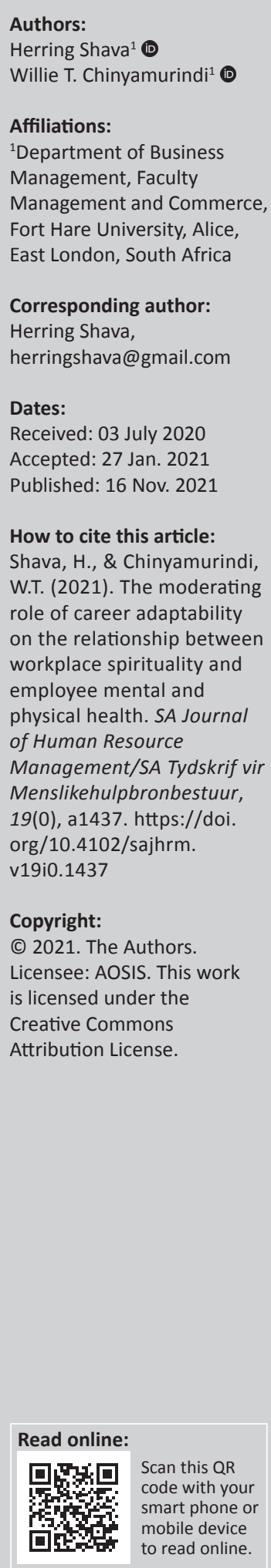

Orientation: Aspects of religion and spirituality are now being infused into the experience of work. The key to this is understanding how religion and spirituality affect individual and organisational functioning.

Research purpose: This study investigated the influence of career adaptability on workplace spirituality and employee health. In this study, employee health refers to mental and physical health.

Motivation for the study: This study's context was the South African public service noted to be undergoing change affecting employees. Strategies that assist employees in promoting mental and physical health are needed.

Research approach/design and method: Quantitative data were gathered through a selfadministered questionnaire, and 214 teachers took part in this study. Simple linear regression and hierarchical regression analyses were performed to make meaning of the data. Respondents of the study were teachers in rural high schools of South Africa.

Main findings: The results indicate that workplace spirituality significantly influences mental and physical health. Furthermore, career adaptability moderates the relationship between workplace spirituality and employee health.

Practical/managerial implications: Given the positive role that workplace spirituality has on employee health, that is, mental and physical health, we advocate for some interventions. This could be in the form of employee-friendly policies. Furthermore, training can assist in developing a heightened sense of individual and organisational workplace spirituality.

Contribution/value-add: Paying attention to how employees develop workplace spirituality and career adaptability can encourage positive behaviours around employee health.

Keywords: Career adaptability; workplace spirituality; mental health; physical health; employee; public service.

\section{Introduction}

The world of work is changing. This change is mostly attributed to most economic and social issues (Skaalvik \& Skaalvik, 2017). These positions, especially within the work psychology stream, continued inquiry from a theoretical and practitioner domain to assist individuals (Savickas, 2019). In such a world of change, the individual needs career adaptability as an important responsive competence (Maree, 2017). This can be in the form of re-planning, re-constructing and re-designing career plans, given the changing environmental context (Rossier, Ginevra, Bollmann, \& Nauta, 2017). Career adaptability is viewed as a critical factor to the individual and the organisation. Links have been between career adaptability with career success, career satisfaction and well-being (Savickas, 1997; Savickas \& Porfeli, 2012). There are continued calls to understand the career adaptability construct (Maree, 2018) and health outcomes (Chinyamurindi, 2019).

For those tasked with assisting with aspects of career counselling, there is a need to rethink practice, especially given the challenges faced (Maree, 2018). The key issue is the individual's response, or the organisation is given an uncertain environment (Doyle, 2017). Possible alternatives are needed to understand contemporary work challenges (Skaalvik \& Skaalvik, 2017). There is a focus on understanding the role of religiosity and spirituality as such alternatives (Garg, 2017; Hill \& Smith, 2010). 
Within the domain of work psychology, there is noted engagement with aspects related to religion and spirituality (e.g. Giacalone \& Jurkiewicz, 2010; eds. Hill \& Dik, 2012; ed. Neal, 2013; Zsolnai \& Flanagan, 2019).

Furthermore, there is an acknowledgement that aspects of religion and spirituality are now being infused into how individuals shape and model their behaviour as agents at an individual and collective level (LoRusso, 2017; Neubert, 2018; eds. Pargament, Mahoney, \& Shafranske, 2013). Some argue that this allows employees to apply themselves to work through heart and soul (Pfeffer, 2010).

In essence, issues such as spirituality can be linked to workrelated outcomes, potentially affecting employees' general well-being (Dong, Wu, Zhu, Jin, \& Zhang, 2017). Ashmos and Duchon (2000) defined workplace spirituality as nourishing the inner life through their work. Subsequently, this can also affect how individuals perceive issues of meaning (Duffy \& Dik, 2013; Duffy, Dik, \& Steger, 2011; Duffy, Douglass, Autin, \& Allan, 2014). Despite these strides, Foster and Foster (2019) noted topics of workplace spirituality as still under-researched. This warrants further empirical attention. Such inquiry angles fit within the need to develop and understand new methods that help individuals cope with the challenges of work (Savickas, 2019). There is a need within the work psychology discipline to focus on aspects of employee health (Follmer \& Jones, 2018) with concepts such as spirituality and religiosity. A starting point is to use Cooper and Williams' (eds. 1994) framing of employee health as consisting of mental and physical health.

The importance of employee health arises from some calls within the literature. A South African study calls for more studies that explore how employees function and flourish within their organisations (Redelinghuys \& Rothmann, 2020). This includes at the core prioritising issues of employee health (Joubert \& Hay, 2019).

Such health expressions for employees consist of physical health (eds. Cooper \& Williams, 1994) and mental health (Chinyamurindi, 2019). Calls exist for more studies that prioritise employee health, especially within organisational contexts (Holland \& Collins, 2020).

\section{The South African public service}

The South African public service is noted to be in a state of flux (Fihla \& Chinyamurindi, 2018) but still acknowledged as an important vehicle in the realisation of service delivery outcomes (Mafini \& Dlodlo, 2014).

Public service employees are considered to be those at the forefront of service delivery to the public. These may include (but are not limited to) teachers and social workers (Barling, Dupré, \& Kelloway, 2009). Despite all this, the South African public service has to address challenges such as (1) maladministration, (2) corruption and (3) wasteful expenditure (Eastern Cape Province Office of the Premier, 2018). Given the nature of such services to the public, workers in the public service are often the target of abuse and aggression (Dick, 2011; Dubois, 2010).

Conversely, all these challenges seem to also have a toll on the agents of this delivery of service to the public, one of them being public employees (Shibiti, 2019). The challenges faced by public employees in their delivery of work outcomes are noted to lead to high turnover (Shibiti, 2019; Zondo, 2018). Calls exist to pay attention to understanding those factors that influence service delivery outcomes for the benefit of the public (Kanyane, 2010; Thornhill \& Van Dijk, 2018). Empirical efforts within the public should be targeted at also ascertaining those factors, favourable or unfavourable, that influence how public employees work (Ijeoma, Nzewi, \& Sibanda, 2013). Organisational interventions like the training provided in the public service can be informed by such evidence-based research (Mbandlwa \& Mishi, 2020; Munzhedzi, 2017), and this can influence efforts towards talent (Ukanwah \& Ndaguba, 2015) and performance management in the public service (Mavhungu \& Bussin, 2017).

Empirical work that exists within the South African public service context attributes a range of factors to influence employee well-being. For instance, the usage of technology has recently been attributed to positively influencing work outcomes and was also found to negatively affect employee well-being (Mahlasela \& Chinyamurindi, 2020). Others (e.g. Jumat, Bezuidenhout, \& Neething, 2014; Mbola, Human, \& Melariri, 2019) found the public service's under-resourced nature to have an impact not only on the outcomes of work but also on the public service employees. Some challenges that affect public service employees have been attributed to have their origin in personal challenges emanating from home and society (Conradie et al., 2017). These subsequently trickle into affecting the work front. These noted challenges can also create psychological distress amongst public service employees (Gumani, 2019). The emphasis as enshrined within the Occupational Health and Safety Act of 1993 is on creating conducive work environments that can promote physical and mental health (Sieberhagen, Rothmann, \& Pienaar, 2009). This focuses on understanding employee health, an important individual, societal and organisational construct (Welthagen \& Els, 2012).

\section{Literature review}

\section{Workplace spirituality, career adaptability and employee health}

Quests for religious and spiritual practices have been attributed to individual consciousness, a sense of purpose, health and general well-being (Tackney et al., 2017). The thinking here is that practices related to workplace spirituality help generate awareness and a sense of connectedness by the individual of themselves, their family, community and natural environment (Sheldrake, 2017). This is supported by theorising that when aspects of work are deemed going well, individuals derive a sense of purpose (Blustein, 2015). A challenge affecting modern-day organisations is around issues of employee health. 
One such employee health issue noted to be on the rise globally (Hasin et al., 2018) and in South Africa concerns mental illness (Chinyamurindi, 2019). Research generally links employee health aspects to a range of outcomes, such as employee productivity (De Vries, Timmer, \& De Vries, 2015). Furthermore, others attribute employee health challenges such as mental illness to be linked to the experience of stigma in the workplace (Elraz, 2018) and a potential source for stereotyping (Follmer \& Jones, 2018). The onus is often on the individual to manage their employee health issues such as mental health, given that organisations (Shann, Martin, \& Chester, 2014) and managers (Martin, Woods, \& Dawkins, 2015) are unaware of strategies of response to assist employees (Martin, 2010).

Concerning the relationship between spirituality, career adaptability and employee health, the extant literature suggests a link amongst these three variables (e.g. Brown, 2003; Hancock, 1997; Mitroff, 2003; Wang, Lesage, Schmitz, \& Drapeau, 2008). The mentioned studies point out that workplace spirituality provides opportunities for employees to perform meaningful work willingly. This potentially results in significant employee benefits, for example, the absence of injuries leading to desired success in terms of physical and mental health. Conversely, Wang et al. (2008) provided evidence indicating that when an employee fails to adapt to career demands, the employee's health deteriorates significantly owing to fatigue and depression. Also, job control is another factor that indicates an individual's ability to adapt to their career. Furthermore, research also shows that low job control leads to poor employee health (Amstad, Meier, Fasel, Elfering, \& Semmer, 2011; Hilton, Sheridan, Cleary, \& Whiteford, 2009). Thus, when career adaptability is present, employee health improves significantly, and when there is a presence of spirituality in the individual, employee health benefits also increase (Altaf \& Awan, 2011; Ahmad \& Omar, 2014; Issa \& Pick, 2011; Karakas, 2010; Prior \& Quinn, 2012; Van der Walt \& De Klerk, 2014).

Research by Rego and Cunha (2007) found that employees who experience workplace spirituality felt more effectively attached to their organisations. Also, Ng and Allen's (2018) research suggested that there is a significant positive relationship between workplace attachment and employee health. It may be correct to assume that workplace spirituality predicts employee health, given that it also predicts workplace attachment, as evidence shows this as a proven predictor of employee health (Dykas \& Cassidy, 2011; Meuwly et al., 2012). Based on the presented literature, it can be expected that:

H1: Workplace spirituality predicts employee mental health.

H2: Workplace spirituality predicts employee physical health.

An assumption can be made about the interaction between workplace spirituality and career adaptability. This interaction can be found in each variable's role in career development or the work-life experience. Harry and Coetzee (2013) flagged demographic factors such as age, gender and meaningfulness on an individual's career adaptability. Research has also pointed out that workplace spirituality enables employees to find meaning and fulfilment in life and in their work (Garg, 2017; Göçen, 2017; Krishnakumar \& Neck, 2002; Petchsawanga \& Duchon, 2012; Smith \& Louw, 2007). This also posits the possibility of using career adaptability as a way to navigate through challenges that may result as part of individual career development (Savickas, 2013). The thinking here is that constructs such as career adaptability can help individuals navigate through their career roles and impose a more meaningful work and home life (Chen et al., 2020).

The context in which public service workers operate has been attributed to a range of challenges. Some researchers attribute the challenge of aggression meted out to public service workers by the public to result in burnout, reduced wellbeing and less organisational commitment (Hershcovis \& Barling, 2010). Others find such experiences to reduce motivation and a desire to serve the public (Vandenabeele, 2008) and aspects of trust (Van de Walle, 2010). Strategies that assist in devising interventions to reduce stress and subsequently promote employee health are needed (Chinyamurindi, 2019). Based on the literature, one such outlet can be through workplace spirituality. Despite such experiences being varied, the argument is how the individual can derive a sense of transcendence by viewing their lives, including work experience, as meaningful and fulfilling a purpose of service to others (Millinan, Gatling, \& BradleyGeist, 2017; Saks, 2011). Based on this presented literature, the following hypotheses are proposed:

H3: Career adaptability moderates the relationship between workplace spirituality and employee mental health such that when career adaptability is high, the relationship between workplace spirituality and employee mental health is stronger.

H4: Career adaptability moderates the relationship between workplace spirituality and employee physical health such that when career adaptability is high, the relationship between workplace spirituality and employee physical health is stronger.

\section{Goal of the study}

This study aimed to investigate the moderating effect of career adaptability on the relationship between workplace spirituality and employee health. The study's specific research question was, 'what is the influence of career adaptability on the relationship between workplace spirituality and employee mental and physical health?' Figure 1 presents the conceptual model tested in this study.

As argued by Pawar (2016), workplace spirituality is an area receiving much empirical attention globally. Such studies are necessary, especially in organisations, as individuals carry aspects related to spirituality in such 


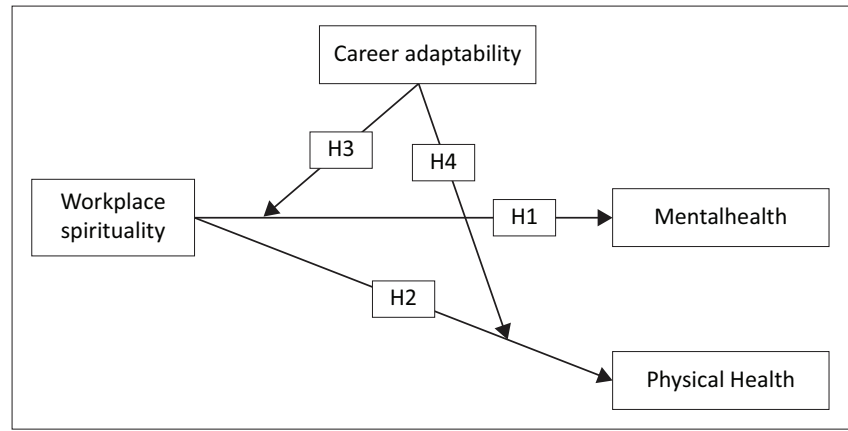

FIGURE 1: Conceptual model.

contexts (Van der Walt \& De Klerk, 2015). In this study, we sought to contribute to this literature and answer such calls by investigating whether workplace spirituality predicts employee health. We went a step further in our quest to understand this proposed relationship, and we factored in career adaptability as a moderating variable (shown in Figure 1). By so doing, we investigated whether career adaptability moderates the relationship between workplace spirituality and employee mental and physical health. To provide answers to proposed relationships, we relied on data collected from a sample of rural public high school educators in South Africa, as explained in the next section.

\section{Method}

\section{Participants and setting}

The study participants comprised a convenience sample of 214 teachers working in the Eastern Cape province of South Africa who were accessed over a 10-month period in 2018. The sample by gender consisted of $54 \%$ women and $46 \%$ men; the sample by race consisted of mostly the black population cohort (95\%) and mixed race people (5\%). About $25 \%$ of the participants were below the age of 30 years, $33 \%$ were between 30 and 40 years, 36\% were between 41 and 50 years, whilst $6 \%$ were in the 51 years and above category. Furthermore, $70 \%$ of the sample had over 10 years of work experience.

\section{Measures}

Given that three main constructs existed in this study, this section reports on the measures used for these constructs. Career adaptability was measured through four subscales on a measure originally designed by Savickas and Porfeli (2012). The career adaptability scale had four subscales: (1) concern, (2) control, (3) curiosity and (4) confidence. The concern subscale was made up of six items. An example of the scale items includes, 'Thinking about what my future will be like'. The control subscale also had six items, and an example of the scale items is, 'Taking responsibility for my actions'. The curiosity subscale also had six items where one of the scale items reads, 'Looking for opportunities to grow'. Finally, the confidence subscale was made up of six scale items, and an example of the scale item is, 'Learning new skills'. All the 24 career adaptability scale items were rated on a five-point Likert scale ( $1=$ not strong and $5=$ strongest $)$.

Workplace spirituality was measured by three dimensions: meaningfulness of work, sense of community and alignment with organisational goals. Other scholars used the work spirituality scale adopted in this study (e.g. Ashmos \& Duchon, 2000; Milliman, Czaplewski, \& Ferguson, 2003). The meaningfulness of the work dimension was measured through four scale items, and an example of the scale items includes, 'I understand what gives my work personal meaning'. The sense of community subscale was made up of four scale items where one of the scale items reads, 'I think employees are linked with a common purpose'. The alignment with the organisational value subscale was made up of four scale items. An example of the scale is, 'My organisation has a conscience - a sense of right or wrong'. All 12 workplace spirituality scale items were measured on a five-point Likert scale, where 1 represents 'strongly disagree' and 5 being the highest rating represented 'strongly agree'.

Employee mental health was measured by a scale with six items developed by Wu (1984). An example of the scale item is, 'During the past 30 days, I have often felt restless or fidgety'.

To measure the employee physical health, a scale developed by Cleeland and Ryan (1994) was adopted. This scale comprises six items, and an example is, 'In the past 30 days, did health issues interfere with walking ability?' Both mental and physical health items were measured on a five-point Likert scale, where 0 represents none of the time and 4 represents all the time.

\section{Procedure}

Participants consented to participate in the study and were approached over a 10-month period at teaching and learning summits organised within the Eastern Cape province of South Africa. These summits would see the gathering together of teachers, and the researchers used the opportunity to collect data through the filling out of a survey. Participants in the study were informed of their rights, including the right to withdraw from the study without any penalty. No identification was made to any participants in the study.

\section{Data analysis}

Given the presented research model in Figure 1, a simple linear regression analysis was utilised to measure direct relationships - the effect of workplace spirituality on employee mental health and physical health. A hierarchical multiple regression analysis was undertaken to measure the moderating effect of career adaptability on employee mental and physical health. The Statistical Package for Social Sciences version 25 was used to perform the statistical analysis. 
TABLE 1: Simple linear regression model fit and summary for workplace spirituality on employee mental health.

\begin{tabular}{|c|c|c|c|c|c|c|c|c|c|}
\hline Source & $d f$ & Sum of squares & Mean squares & $F$ & $\operatorname{Pr}>F$ & $r$ & $R^{2}$ & Adjusted $R^{2}$ & Estimated standard error \\
\hline Model summary & - & - & - & - & - & 0.427 & 0.183 & 0.179 & 3.87661 \\
\hline Regression & 1 & 711.608 & 711.608 & 47.352 & $0.000 *$ & - & - & - & - \\
\hline Residual & 212 & 3185.962 & 15.028 & - & - & - & - & - & - \\
\hline Total & 213 & 3889.570 & - & - & - & - & - & - & - \\
\hline
\end{tabular}

Note: Predictor variable: workplace spirituality; Outcome variable: mental health.

*, Significant fit at $p<0.05$

\section{Ethical considerations}

Ethical clearance was obtained from the University of Fort Hare Research Ethics Committee (reference number CHI151SHAR01).

\section{Results}

\section{Outcomes of reliability tests}

We performed reliability tests of the career adaptability scale and found associated Cronbach's alpha coefficients as follows: concern (0.735), control (0.718), curiosity (0.742) and confidence (0.739). The Cronbach's alpha coefficient scores of the workplace spirituality subscales were 0.804 for the meaningfulness of work, 0.821 for alignment with organisational values and 0.762 for the sense of community scale. The mental health taken from a previous study $(\mathrm{Wu}, 1984)$ yielded a Cronbach's alpha coefficient score of 0.751 , and the physical health scale had a Cronbach's alpha coefficient score of 0.80 . Based on the analysis we conducted, all scales used yielded a Cronbach's alpha coefficient above the recommended threshold of 0.7 (Cronbach, 1951; Nunnally, 1978).

\section{Workplace spirituality and employee mental health}

This study hypothesised that workplace spirituality predicts employee mental health. Before the simple linear regression was performed, the independent variable (IV) and the dependent variable (DV) data were checked to determine whether it had adhered to normality assumptions. The normality tests, that is, the Kolmogorov-Smirnov and the Shapiro-Wilk tests, were performed and observed, and the results for both tests, the IV and the DV data, have a $p$-value of less than 0.05 , indicating that the data did not conform to the assumptions of normality. As a result, the researchers had to perform the simple linear regression analysis with bootstrapped confidence intervals (CIs) and their significance levels as these do not rely on assumptions of normality and homoscedasticity.

The simple linear regression analysis was performed with workplace spirituality as an IV and employee mental health as a DV. The results revealed a moderate positive correlation between workplace spirituality and employee mental health $(r=0.427)$. Furthermore, the results revealed that workplace spirituality accounts for $18.3 \%$ of the variation in employee mental health $\left(R^{2}=0.183\right)$. The results further informed us that approximately $82 \%$ of the variation in employee mental health is explained by factors other than workplace spirituality, which are not accounted for by this model.
TABLE 2: Parameter estimates for workplace spirituality on employee mental health Parameter Unstandardised co-efficient

\begin{tabular}{lccc}
\cline { 2 - 4 } & $\boldsymbol{B}$ & Standard error & Significance \\
\hline Constant & 17.323 & 1.483 & $0.000^{*}$ \\
Workplace spirituality & 0.190 & 0.028 & $0.000^{*}$ \\
\hline
\end{tabular}

Note: Predictor: workplace spirituality; Outcome: mental health.

$*$, Significant at $p<0.05$.

However, if we are to better understand the concept of employee mental health, this result suggests that it is worth paying special attention to workplace spirituality. Given this result, Cohen's $f^{2}$ or the regression effect, which measures the IV impact on the DV, is 0.224 . In other words, the impact of workplace spirituality on employee mental health ranges from medium to large. The Cohen's $f^{2}$ was derived using the formula $R^{2} /\left(1-R^{2}\right)$. The $F$ ratio that seeks to explain whether the use of the model in predicting employee mental health was significantly better than relying on the mean value of employee mental health was examined, and the results revealed a significant $F=47.352$ at $p<0.05$. In other words, making use of this model is significantly better in predicting employee mental health as opposed to making use of the employee mental health mean value. Table 1 summarises the above results.

The estimates of the model were observed as $b_{0}=17.323$ and $b_{1}=$ 0.19 . The $b_{1}$ value represents a change in the outcome variable because of a unit change in the explanatory variable; and from this result, we learn that a unit change in workplace spirituality results in a corresponding positive change in employee mental health of 0.19 units. More importantly, this change is significant at $p<0.05$. In other words, the hypothesis stating that workplace spirituality predicts employee mental health is supported. The discussed results are summarised in Table 2.

\section{Workplace spirituality and employee physical health}

To test the hypothesis stating that workplace spirituality predicts employee physical health, the IV and the DV data were examined to determine whether it adhered to normality assumptions. Both the Kolmogorov-Smirnov and the Shapiro-Wilk tests were examined, and the results pointed out that the IV and the DV data violated the assumptions of normality as the $p$-values were less than 0.05 . Given that the data did not adhere to normality assumptions, the simple linear regression analysis was performed, and bootstrapped CIs and their significance levels were requested as these do not rely on assumptions of normality and homoscedasticity.

In the simple linear regression model, workplace spirituality was the explanatory variable, and employee 
physical health was the outcome variable. The model summary results indicated a weak to moderate positive relationship between workplace spirituality and employee physical health $(r=0.382)$.

Furthermore, it was observed that workplace spirituality accounted for $14.6 \%$ of the variance in employee physical health $\left(R^{2}=0.146\right)$. This implies that approximately $85 \%$ of the variation in employee physical health is accounted for by factors other than workplace spirituality. Cohen's $f^{2}$ given as the stated formula gives us the result of 0.171 , which informs us that workplace spirituality has a medium impact on employee physical health.

However, if we are to extend our understanding of employee physical health, the stated results suggest that it is worth paying more attention to the concept of workplace spirituality. The F-ratio results explaining whether the model is significantly better in predicting employee physical health than relying on the mean value of employee physical health revealed that $F=$ 36.193 and significant at $p<0.05$. This result means that the model is significantly better in predicting employee physical health than relying on the mean value of employee physical health. The discussed results are presented in Table 3.

The estimates of the model were observed as $b_{0}=21.055$ and $b_{1}=0.152$. The value of $b_{1}$ represents a unit change in the outcome variable because of a unit change in the explanatory variable. From this result, we learn that a unit change in workplace spirituality will result in a corresponding positive charge equal to 0.152 units in employee physical health. This change is significant at $p<0.05$. Given this result, we fail to reject the hypothesis stating that workplace spirituality predicts employee physical health as there is enough evidence to back this claim. The results discussed are outlined in Table 4 .

\section{Linear predictors of mental health}

H3: Career adaptability moderates the relationship between workplace spirituality and employee mental health such that when career adaptability is high, the relationship between workplace spirituality and employee mental health is stronger.

To examine the stated hypothesis, a hierarchical multiple linear regression analysis was performed with career adaptability as a moderating variable, workplace spirituality as the IV and employee mental health as the DV.

The study results focusing on the conditional effects of the IV on the DV at values of the moderator indicated that (1) when career adaptability is low, to be precise when career adaptability is -4.62 , there is a non-significant positive relationship between workplace spirituality and employee mental health $(b=0.046,95 \%$ CI $[-0.031,0.123], t=1.17$, $p=0.241)$; (2) when career adaptability is -1.62 , there is a significant positive relationship between workplace spirituality and employee mental health $(b=0.075,95 \% \mathrm{CI}$ [0.0111, 0.138], $t=2.316, p=0.02$ ); and (3) when career adaptability is high at 4.379 , there is a significant positive relationship between workplace spirituality and employee mental health $(b=0.0132,95 \%$ CI [0.06, 0.204], $t=3.618$, $p=0.0004)$. Table 5 presents these results.

The Johnson-Neyman method was further examined, and it revealed that the threshold for significance between workplace spirituality and employee mental health relationship ends when career adaptability is equal to -2.48 , and this value, a weak but positive significant relationship between workplace spirituality and employee mental health is observed ( $b=0.066,95 \% \mathrm{CI}[0.000,0.133], t=1.971, p=0.05)$. The results are presented in Table 6 .

TABLE 3: Simple linear regression model fit and summary for workplace spirituality on employee physical health.

\begin{tabular}{lcccccccc}
\hline Source & $d f$ & Sum of squares & Mean squares & $\boldsymbol{F}$ & $\operatorname{Pr}>\boldsymbol{F}$ & $\boldsymbol{r}$ & $\boldsymbol{R}^{2}$ & ${\text { Adjusted } \boldsymbol{R}^{2}}^{\text {Estimated standard error }}$ \\
\hline Model summary & - & - & - & - & - & 0.382 & 0.146 & 0.142 \\
Regression & 1 & 458.089 & 458.089 & 36.193 & $0.000 *$ & - & - \\
Residual & 212 & 2683.219 & 12.657 & - & - & - & - \\
\hline Total & $\mathbf{2 1 3}$ & $\mathbf{3 1 4 1 . 3 0 8}$ & - & - & - & - & - & - \\
\hline
\end{tabular}

Note: Predictor variable: workplace spirituality; Outcome variable: physical health.

*, Significant fit at $p<0.05$

TABLE 4: Parameter estimates for workplace spirituality on employee physical health.

\begin{tabular}{lccc}
\hline Parameter & \multicolumn{3}{c}{ Unstandardised co-efficient } \\
\cline { 2 - 5 } & $\boldsymbol{B}$ & Standard error & Significance \\
Constant & 21.055 & 1.361 & $0.000^{*}$ \\
Workplace spirituality & 0.152 & 0.025 & $0.000 *$ \\
\hline
\end{tabular}

Note: Predictor: workplace spirituality; Outcome: physical health.

$*$, Significant at $p<0.05$.

TABLE 5: Conditional effects of the focal predictor at values of the moderator(s).

\begin{tabular}{|c|c|c|c|c|c|c|}
\hline Career adaptability & Effect & SE & $t$ & $p$ & LLCI & ULCI \\
\hline-4.6215 & 0.0460 & 0.0391 & 1.1745 & 0.2415 & -0.0312 & 0.1231 \\
\hline-1.6215 & 0.0746 & 0.0322 & 2.3157 & 0.0215 & 0.0111 & 0.1380 \\
\hline 4.3785 & 0.1317 & 0.0364 & 3.6176 & 0.0004 & 0.0599 & 0.2035 \\
\hline
\end{tabular}

LLCI, lower level of confidence interval; ULCI, upper level of confidence interval; SE, standard error.

Focal predictor: workplace spirituality; Moderating variable: career adaptability; Outcome variable: mental health. 
TABLE 6: Conditional effects of the focal predictor at values of the moderator(s)/Johnson-Neyman significance region(s).

\begin{tabular}{lcccccc}
\hline Career adaptability & Effect & SE & $\boldsymbol{t}$ & $\boldsymbol{p}$ & LLCI & ULCI \\
\hline-14.6215 & -0.0493 & 0.0792 & -0.6227 & 0.5341 & -0.2054 & 0.1068 \\
-2.4776 & 0.0664 & 0.0337 & 1.9713 & 0.0500 & 0.0000 & 0.1328 \\
18.3785 & 0.2651 & 0.0929 & 2.8522 & 0.0048 & 0.0819 & 0.4483 \\
\hline
\end{tabular}

$\mathrm{LLCl}$, lower level of confidence interval; ULCI, upper level of confidence interval; SE, standard error.

Moderator value(s) defining Johnson-Neyman significance regions: Value: $-2.4776, \%$ below: $36.4486, \%$ above: 63.5514 .

Focal predictor: workplace spirituality; Moderating variable: career adaptability; Outcome variable: mental health.

TABLE 7: Bootstrap results for employee mental and physical health.

\begin{tabular}{lcccc}
\hline Linear model of predictors & $\boldsymbol{b}$ & Boot LLCl and Boot ULCI & Boot SE & Boot mean \\
\hline Employee mental health & - & - & - & - \\
Constant & 27.0939 & $26.4721-27.7153$ & 0.3153 & 27.0861 \\
Career adaptability & 0.2509 & $0.1288-0.3829$ & 0.0645 & 0.2544 \\
Workplace spirituality & 0.0900 & $0.0157-0.1636$ & & 0.0884 \\
Career adaptability*workplace spirituality & 0.009 & $0.0012-0.0206$ & 0.0050 & 0.0099 \\
Employee physical health & - & - & 0.3612 & - \\
Constant & 28.8712 & $28.1312-29.5561$ & 0.1041 & 0.218609 \\
Career adaptability & 0.1555 & $-0.0607-0.3427$ & 0.0363 & 0.1539 \\
Workplace spirituality & 0.0843 & $0.0137-0.1564$ & 0.0071 & 0.0849 \\
Career adaptability* workplace spirituality & 0.0085 & $-0.0047-0.0234$ & & 0.0088 \\
\hline
\end{tabular}

$\mathrm{LLCl}$, lower level of confidence interval; ULCI, upper level of confidence interval; SE, standard error.

TABLE 8: Conditional effects of the focal predictor at values of the moderator(s).

\begin{tabular}{|c|c|c|c|c|c|c|}
\hline Career adaptability & Effect & SE & $t$ & $p$ & LLCl & ULCI \\
\hline-4.6215 & 0.0451 & 0.0372 & 1.2124 & 0.2267 & -0.0282 & 0.1184 \\
\hline-1.6215 & 0.0705 & 0.0306 & 2.3062 & 0.0221 & 0.0102 & 0.1308 \\
\hline 4.3785 & 0.1215 & 0.0346 & 3.5110 & 0.0005 & 0.0533 & 0.1896 \\
\hline
\end{tabular}

$\mathrm{LLCl}$, lower level of confidence interval; ULCI, upper level of confidence interval; SE, standard error.

Focal predictor: workplace spirituality; Moderating variable: career adaptability; Outcome variable: physical health.

The Johnson-Neyman method also revealed that with increases in the value of career adaptability, the relationship between workplace spirituality and employee mental health goes from a small significant positive relationship ( $b=0.066, p=0.05)$ to a fairly stronger significant positive relationship $(b=0.27, p=0.0048)$ at career adaptability $=$ 19.38. Given this outcome, we fail to reject the null hypothesis as there is enough evidence to support the study's claim and conclude that when career adaptability is high, the relationship between workplace spirituality and employee mental health is significant and stronger. Table 7 presents bootstrapped results of the linear predictors of employee mental and physical health. The value of $R^{2}=$ 0.3023 in relation to linear predictors of mental health is observed, and with it, the Cohen's $f^{2}$ is derived as 0.43 . This indicates that the effect of workplace spirituality on employee mental health in the presence of the moderating variable (i.e. career adaptability) is substantial. The results mean that in order for workplace spirituality to have a meaningful impact on employee mental health in the workplace, intervention measures should be designed to enhance employee career adaptability.

\section{Linear predictors of physical health}

H4: Career adaptability moderates the relationship between workplace spirituality and employee physical health such that when career adaptability is high, the relationship between workplace spirituality and employee physical health is stronger.
To investigate the stated hypothesis, a hierarchical multiple linear regression analysis was performed with career adaptability as a moderating variable, workplace spirituality as the IV and employee physical health as the DV. The study results, shown in Table 8, explaining the conditional effects of IV on the DV at values of moderating variable revealed that (1) when career adaptability is low, to be precise career adaptability is -4.622 , there is a non-significant positive relationship between workplace spirituality and employee physical health $(b=0.045,95 \%$ CI $[-0.028,0118], t=1.212$, $p=0.227$; (2) when career adaptability is -1.622 , there is a significant positive relationship between workplace spirituality and employee physical health $(b=0.071,95 \% \mathrm{CI}$ [0.01, 0.131], $t=2.31, p=0.022)$; and (3) when career adaptability is high, that is, 4.379 , there is a significant positive relationship between workplace spirituality and employee physical health $(b=0.122,95 \%$ CI $[0.053,0.190]$, $t=3.51, p=0.000)$.

Furthermore, the output of the Johnson-Neyman method was examined, as shown in Table 9, and it revealed that career adaptability value of -2.49 was the minimum threshold for a significant positive relationship between workplace spirituality and employee physical health $(b=0.063,95 \% \mathrm{CI}$ [0.000, 0.13], $t=1.97, p=0.05)$. The results further revealed that as the career adaptability values increased, the strength of the relationship between workplace spirituality and employee physical health grew from a small significant positive effect (i.e. career adaptability is $-2.494, b=0.063$, $p=0.05)$ to a relatively strong significant positive effect 
TABLE 9: Conditional effects of the focal predictor at values of the moderator(s)/Johnson-Neyman significance region(s).

\begin{tabular}{lcccccc}
\hline Career adaptability & Effect & SE & $\boldsymbol{t}$ & $\boldsymbol{p}$ & ULCI & 0.1880 \\
-14.6215 & -0.0398 & 0.0752 & -0.5287 & 0.1085 & 0.0500 & 0.0000 \\
-2.4935 & 0.0631 & 0.0320 & 1.9713 & 0.1263 & 0.0071 & 0.0662 \\
18.3785 & 0.2402 & 0.0883 & 2.7206 & 0.4143 & \\
\hline
\end{tabular}

$\mathrm{LLCl}$, lower level of confidence interval; ULCI, upper level of confidence interval; SE, standard error.

Moderator value(s) defining Johnson-Neyman significance regions: Value: $-2.4935, \%$ below: $36.446, \%$ above: 63.5514 .

Focal predict: workplace spirituality; Moderating variable: career adaptability; Outcome variable: physical health.

(career adaptability is $18.38, b=0.24, p=0.007$ ). Given this result, the study fails to reject the hypothesis, stating that career adaptability moderates the relationship between workplace spirituality and employee physical health as there is enough evidence to support this claim. This result means that career adaptability plays a pivotal role in the relationship between workplace spirituality and employee physical health. Also, the Cohen's $f^{2}$ equal to 0.28 reveals that workplace spirituality in the presence of a moderating variable (career adaptability) has an above-average impact on employee physical health. In other words, in order for workplace spirituality to have a meaningful impact on employee physical health, an intervention mechanism targeted at enhancing employee career adaptability issues should be designed.

\section{Discussion}

The study aimed at investigating the influence of career adaptability on the relationship between workplace spirituality and employee health. Based on the findings of this study, career adaptability is framed as an important construct in the career development process (Maree, 2017; Rossier et al., 2017; Savickas et al., 2009). We illustrate this in a threefold manner.

Firstly, we place focus on a context that is noted to be in a state of flux (Fihla \& Chinyamurindi, 2018) in the form of the South African public service. Through this study, we proffer solutions to some of the South African public service challenges, especially given the documented employee challenges (Ijeoma et al., 2013; Shibiti, 2019; Zondo, 2018). Secondly, concerning workplace spirituality, we suggest this as a possible intervention that can be encouraged to assist in public service employees' well-being. The study results provide evidence that workplace spirituality has an impact on employee mental health that is above average (Cohen's $f^{2}=0.224$ ) and an impact on employee physical health that is slightly above average. These findings are in line with previous researches which concluded that workplace spirituality positively predicts employee mental health (Dykas \& Cassidy, 2011; Meuwly et al., 2012; Ng \& Allen, 2018).

Finally, our study illustrates the importance of career adaptability away from factors such as a person's career success, satisfaction and well-being (Dong et al., 2017; Savickas, 1997; Savickas \& Porfeli, 2012) to focus on employee mental and physical health outcomes. As observed, in the presence of career adaptability, the impact of workplace spirituality on employee mental health is large $\left(\right.$ Cohen's $\left.f^{2}=0.43\right)$.

Similarly, in the presence of career adaptability, the impact of workplace spirituality on employee physical health is slightly below large (Cohen's $f^{2}=0.28$ ). This finding concurs with the empirical evidence which pointed out that when career adaptability is present, there is an improvement in employee health, that is, both mental and physical health (Ahmad \& Omar, 2014; Altaf \& Awan, 2011; Issa \& Pick, 2011; Karakas, 2010; Prior \& Quinn, 2012; Van der Walt \& De Klerk, 2014).

In essence, through this study, we answer calls to more studies exploring workplace spirituality (Foster \& Foster, 2019; Garg, 2017; Hill \& Smith, 2010). In essence, workplace spirituality and career adaptability can exist as useful contemporary competencies that help employees cope with the challenge of work (Savickas, 2019) and improve their health, albeit in an everchanging environment.

\section{Implications}

Some practical implications can be drawn from this study. Firstly, given the positive role of workplace spirituality on employee health (both mental and physical health), we advocate for some interventions. These could be in the form of encouraging employees regarding issues related to workplace spirituality. This could be in the form of employeefriendly policies.

Furthermore, training can assist in developing a heightened sense of individual and organisational workplace spirituality. Secondly, given the moderating role of career adaptability on the relationship between workplace spirituality and employee health, support intervention that assists employee adaptability to changes can be provided. This can be done through an effective and efficient ongoing programme of career counselling that focuses on developing aspects of workplace spirituality to improve employee health. A point of departure could be to identify and address those inhibitors of career adaptability and workplace spirituality.

\section{Limitations}

Out study has some limitations. We acknowledge challenges with obtaining a reliable sampling frame. Therefore, caution should be exercised not only when interpreting the findings of this research but also when 
concerning generalisability issues. Our study utilised selfreport measures, which may potentially result in issues of social desirability bias.

\section{Future research}

Future research could also utilise qualitative research methods to capture the ensuing complexity that can arise out of career adaptability as a processual activity, including the role of workplace spirituality in such processes.

Furthermore, it will be interesting for a multi-industry study to ascertain whether any variation potentially exists. Our study heightens focus on the role of workplace spirituality and career adaptability on employee health amongst a sample of public service employees. Our study is a useful basis for providing evidence to improve employee health quests through individual and organisation interventions.

\section{Conclusion}

This research provides evidence for the role of workplace spirituality as an organisational variable and its influence on employee health to include mental and physical health. The findings become relevant, especially within a changing workplace that should be cognisant of the role of values such as spirituality. This becomes critical, especially in some workplace contexts laden with challenges putting a physical and mental strain on employees. In addition to workplace spirituality, individual experiences of career adaptability are also important in assisting employees.

\section{Acknowledgements}

The researchers acknowledge the role of the respondents in the public service for taking part in the survey.

\section{Competing interests}

The authors declare that they have no competing interest that may have influenced the undertaking of this research.

\section{Authors' contributions}

H.S. and W.T.C. conceptualised and designed the study. W.T.C. structured, wrote part of the literature review and discussed the results. H.S. also undertook literature review, oversaw the data collection, carried out the analysis and reported the results.

\section{Funding information}

This study was funded by the South African Medical Research Council under the Self-Initiated Research Grant awarded to Prof Willie Chinyamurindi between 2018 and 2020. Additional funding was sourced internally at the University of Fort Hare, Faculty of Management and Commerce's Research Niche Area.

\section{Data availability}

The data that support the findings of this study are available from the corresponding author, [H.S.], upon reasonable request.

\section{Disclaimer}

The views and opinions expressed in this article are those of the authors and are not an official position of the institution or funder.

\section{References}

Ahmad, A., \& Omar, Z. (2014). Reducing deviant behavior through workplace spirituality and job satisfaction. Asian Social Science, 10(19), 107-112. https://doi. org/10.5539/ass.v10n19p107

Altaf, A., \& Awan, M.A. (2011). Moderating effect of workplace spirituality on the relationship of job overload and job satisfaction. Journal of Business Ethics, 104(1), 93-99. https://doi.org/10.1007/s10551-011-0891-0

Amstad, F., Meier, L., Fasel, U., Elfering, A., \& Semmer, N. (2011). A meta-analysis of work-family conflict and various outcomes with a special emphasis on crossdomain versus matching- domain relations. Journal of Occupational Health Psychology, 16(2), 151-169. https://doi.org/10.1037/a0022170

Ashmos, D.P., \& Duchon, D. (2000). Spirituality at work: A conceptualization and measure. Journal of Management Inquiry, 9(2), 134-145. https://doi. org/10.1177/105649260092008

Barling, J., Dupré, K.E., \& Kelloway, E.K. (2009). Predicting workplace aggression and violence. Annual Review of Psychology, 60, 671-692. https://doi.org/10.1146/ annurev.psych.60.110707.163629

Blustein, D.L. (2019). The importance of work in an age of uncertainty: The eroding work experience in America. New York: Oxford University Press.

Brown, R.B. (2003). Organizational spirituality: The sceptic's version. Organization, 10(2), 393-400. https://doi.org/10.1177/1350508403010002013

Chen, H., Fang, T., Liu, F., Pang, L., Wen, Y., Chen, S., \& Gu, X. (2020). Career adaptability research: A literature review with scientific knowledge mapping in web of science. International Journal of Environmental Research Public Health, 17(16), 1-21. https://doi.org/10.1155/2020/9793425

Chinyamurindi, W.T. (2019). Mental health research in African organisations: Advancing theory and practice. South African Journal of Industrial Psychology, 45(0), a1727. https://doi.org/10.4102/sajip.v45i0.1727

Cleeland, C.S., \& Ryan, K.M. (1994). Pain assessment: The global use of the Brief Pain Inventory. Annals Academy of Medicine Singapore, 23(2), 129-138.

Conradie, M., Erwee, D., Serfontein, I., Visser, M., Calitz, F.J.W., \& Joubert, G. (2017). A profile of perceived stress factors among nursing staff working with intellectually disabled in-patients at the Free State psychiatric complex, South Africa. Curationis, 40(1), 1-8. https://doi.org/10.4102/curationis.v40i1.1578

Cooper, C.L., \& Williams, S. (Eds.). (1994). Creating healthy work organizations. Chichester, UK: University of Michigan, John Wiley Sons.

Cronbach, L.J. (1951). Coefficient alpha coefficient and the internal structure of tests. Psychometrika, 16, 297-334. https://doi.org/10.1007/BF02310555

De Vries, G.J., Timmer, M.P., \& De Vries, K. (2015). Structural transformation in Africa: Static gains, dynamic losses. Journal of Development Studies, 51(6), 1-15. https:// doi.org/10.1080/00220388.2014.997222

Dick, G.P. (2011). The influence of managerial and job variables on organizational commitment in the police. Public Administration, 89(2), 557-576. https://doi. org/10.1111/j.1467-9299.2010.01874.x

Dong, M., Wu, S., Zhu, Y., Jin, S., \& Zhang, Y. (2017). Secular examination of spiritualityprosociality association. Archive for the Psychology of Religion, 39(1), 61-81. https://doi.org/10.1163/15736121-12341332

Doyle, A. (2017). How often do people change jobs? The balance careers. Retrieved from https://www.thebalancecareers.com/how-often-do-people-change-jobs2060467

Dubois, V. (2010). The bureaucrat and the poor: Encounters in French welfare offices. Aldershot: Ashgate.

Duffy, R.D., \& Dik, B.J. (2013). Research on calling: What have we learned and where are we going? Journal of Vocational Behaviour, 83(3), 428-436. https://doi. org/10.1016/j.jvb.2013.06.006

Duffy, R.D., Dik, B.J., \& Steger, M. (2011). Calling and work-related outcomes: Career commitment as a mediator. Journal of Vocational Behaviour, 78(2), 210-218. https://doi.org/10.1016/j.jvb.2010.09.013

Duffy, R.D., Douglass, R.P., Autin, K.L., \& Allan, B.A. (2014). Examining predictors and outcomes of a career calling among undergraduate students. Journal of Vocational Behaviour, 85(3), 309-318. https://doi.org/10.1016/j.jvb.2014.08.009

Dykas, M.J., \& Cassidy, J. (2011). Attachment and the processing of social information across the life span: Theory and evidence. Psychological Bulletin, 137(1), 19-46. https://doi.org/10.1037/a0021367

Eastern Cape Province Office of the Premier. (2018). Annual report: 2017/2018 - Vote 1. EC Provincial Government of South Africa. Retrieved from http://www.ecprov. gov.za/KnowledgeHub/Documents/Annual\%20Report\%20(2017-18).pdf 
Elraz, H. (2018). Identity, mental health and work: How employees with mental health conditions recount stigma and the pejorative discourse of mental illness. Human Relations, 71(5), 722-741. https://doi.org/10.1177/0018726717716752

Fihla, S., \& Chinyamurindi, W. (2018). Human resources management practices on employee commitment: The case of a local municipality in South Africa. Journal of Public Administration, 53(2), 215-233.

Follmer, K.B., \& Jones, K.S. (2018). Mental illness in the workplace: An interdisciplinary review and organizational research agenda. Journal of Management, 44(1), 325-351. https://doi.org/10.1177/0149206317741194

Foster, S., \& Foster, A. (2019). The impact of workplace spirituality on work-based learners: Individual and organisational level perspectives. Journal of Work-Applied Management, 11(1), 63-75. https://doi.org/10.1108/JWAM-06-2019-0015

Garg, N. (2017). Workplace spirituality and employee well-being: An empirical exploration. Journal of Human Values, 23(2), 129-147. https://doi. org/10.1177/0971685816689741

Giacalone, R.A., \& Jurkiewicz, C.L. (2010). Handbook of workplace spirituality and organizational performance (2nd edn.). New York: M. E. Sharpe.

Göçen, A. (2017). An experimental implementation to develop workplace spirituality in educational organizations. Unpublished doctoral thesis. Gaziantep University Educational Sciences.

Gumani, M.A. (2019). The influence of organisational stressors on the well-being and performance of operational police members. South African Journal of Industrial Psychology, 45, 1-14. https://doi.org/10.4102/sajip.v45i0.1674

Hancock, P.G. (1997). Citizenship or vassalage? Organizational membership in the age of unreason. Organization, 4(1), 93-111. https://doi.org/10.1177/13505084 9741006

Harry, N., \& Coetzee, M. (2013). Sense of coherence, career adaptability and burnout of early-career Black staff in the call centre environment. South African Journal of Industrial Psychology, 39(2), 1-10. https://doi.org/10.4102/sajip.v39i2.1138

Hasin, D.S., Sarvet, A.L., Meyers, J.L., Saha, T.D., Ruan, W.J., Stohl, M., \& Grant, B.F. (2019). Epidemiology of adult DSM-5 major depressive disorder and its specifiers in the United States. JAMA Psychiatry, 75(4), 336-346. https://doi.org/10.1001/ jamapsychiatry.2017.4602

Hershcovis, M.S., \& Barling, J. (2010). Towards a multi-foci approach to workplace aggression: A meta-analytic review of outcomes from different perpetrators. Journal of Organizational Behaviour, 31(1), 24-44. https://doi.org/10.1002/ job.621

Hill, P.C., \& Dik, B.J. (Eds.). (2012). Psychology of religion and workplace spirituality. Charlotte, NC: Information Age Publish.

Hill, P. C., \& Smith, G. S. (2010). Coming to terms with spirituality and religion in the workplace. In R.A. Giacalone \& C.L. Jurkiewicz (Eds.), The handbook of workplace spirituality and organizational performance (2nd edn., pp. 171-184). New York: M. E. Sharpe.

Hilton, M.F., Sheridan, J., Cleary, C.M., \& Whiteford, H.A. (2009). Employee absenteeism measures reflecting current work practices may be instrumental in a re-evaluation of the relationship between psychological distress/mental health and absenteeism. International Journal of Methods in Psychiatric Research, 18(1), 37-47. https://doi.org/10.1002/mpr.275

Holland, P., \& Collins, A.M. (2020). Supporting and retaining employees with rheumatoid arthritis: The importance of workplace social support. The International Journal of Human Resource Management, 1-22. https://doi.org/10. 1080/09585192.2020.1737175

Ijeoma, E., Nzewi, O., \& Sibanda, M. (2013). South Africa's public administration for community development. Pretoria: Verity Publishers.

Issa, T., \& Pick, D. (2011). Ethical mindsets in the Australian services sector. Asia Pacific Journal of Business and Management, 1(1), 29-42.

Joubert, C., \& Hay, J. (2019). Capacitating postgraduate education students with lay counselling competencies via the culturally appropriate bibliotherapeutic readme-to-resilience intervention. South African Journal of Education, 39(3), 1-13. https://doi.org/10.15700/saje.v39n3a1543

Jumat, J.D., Bezuidenhout, M.C., \& Neethling, T.G. (2014). Pre-deployment preparation of military nurses of the South African National Defence Force for participation in peace support operations. Curationis, 37(1), 1-9. https://doi.org/10.4102/ curationis.v37i1.75

Kanyane, M.H. (2010). Public service delivery issues in question. In K. Kondo \& M.H. Maserumule (Eds.), The Zuma administration: Critical challenges (pp. 77-94) Pretoria: HSRC Press.

Karakas, F. (2010). Spirituality and performance in organizations: A literature review. Journal of Business Ethics, 94(1), 89-106. https://doi.org/10.1007/s10551-0090251-5

Krishnakumar, S., \& Neck, C.P. (2002). The "what," "why" and "how" of spirituality in the workplace. Journal of Managerial Psychology, 17(3), 153-164. https://doi. org/10.1108/02683940210423060

LoRusso, J.D. (2017). Spirituality, corporate culture, and American business. New York: Bloomsbury Academic Publishing.

Mafini, C., \& Dlodlo, N. (2014). The relationship between extrinsic motivation, job satisfaction, and life satisfaction amongst employees in a public organisation. South African Journal of Industrial Psychology, 4O(1), 1-13. https://doi. org/10.4102/sajip.v40i1.1166

Mahlasela, S., \& Chinyamurindi, W.T. (2020). Technology-related factors and their influence on turnover intentions: A case of government employees in South Africa. The Electronic Journal of Information Systems in Developing Countries, 86(3), e12126. https://doi.org/10.1002/isd2.12126
Maree, J.G. (2018). Contextualisation is a determining factor for career counselling throughout the world. In J.A. Athanasou \& H.N. Perera (Eds.), International handbook of career guidance (2nd edn., pp. 555-578). Switzerland: Springer International Publishing.

Maree, K. (2017). Psychology of career adaptability, employability and resilience. Switzerland: Springer International Publishing.

Martin, A. (2010). Individual and contextual correlates of managers' attitudes towards depressed employees. Human Resource Management, 49(4), 647-668. https:// doi.org/10.1002/hrm.20370

Martin, A., Woods, M., \& Dawkins, S. (2015). Managing employees with mental health issues: Identification of conceptual and procedural knowledge for development within management education curricula. Academy of Management Learning \& Education, 14(1), 50-68. https://doi.org/10.5465/amle.2012.0287

Mavhungu, D., \& Bussin, M.H.R. (2017). The mediation role of motivation between leadership and public sector performance. South African Journal of Human Resource Management, 15, 1-11. https://doi.org/10.4102/sajhrm.v15i0.840

Mbandlwa, Z., \& Mishi, S. (2020). Ward councillors' leadership characteristics and their impact on service delivery: Case of eThekwini Metropolitan Municipality, South Africa, in 2018. Journal of Local Government Research and Innovation, 1, 1-13. https://doi.org/10.4102/jolgri.v1i0.5

Mbola, P., Human, I.S., \& Melariri, P.E. (2019). Environmental health community service: Confronting the human resource challenges. South African Journal of Human Resource Management, 17, 1-10. https://doi.org/10.4102/sajhrm.v17i0.1135

Meuwly, N., Bodenmann, G., Germann, J., Bradbury, T.N., Ditzen, B., \& Heinrichs, M. (2012). Dyadic coping, insecure attachment, and cortisol stress recovery following experimentally induced stress. Journal of Family Psychology, 26(6), 937-947. https://doi.org/10.1037/a0030356

Milliman, J., Czaplewski, A.J., \& Ferguson, J. (2003). Workplace spirituality and employee work attitudes: An exploratory empirical assessment. Journal of Organizational Change Management, 16(4), 426-447. https://doi org/10.1108/09534810310484172

Milliman, J., Gatling, A., \& Bradley-Geist, J.C. (2017). The implications of workplace spirituality for person-environment fit theory. Psychology of Religion and Spirituality, 9(1), 1-12. https://doi.org/10.1037/rel0000068

Mitroff, I.I. (2003). Do not promote religion under the guise of spirituality. Organization, 10(2), 375-382. https://doi.org/10.1177/1350508403010002011

Munzhedzi, P.H. (2017). A reflection on the relationship between performance management and training in the South African public service. South African sajhrm.v15i0.864

Neal, J. (Ed.). (2013). Handbook of faith and spirituality in the workplace. Switzerland Springer International Publishing.

Neubert, M.J. (2018). With or without spirit: Implications for scholarship and leadership. Academy of Management Perspectives, 33(3), 253-263. https://doi. org/10.5465/amp.2016.0172

Ng, T.W.H., \& Allen, T.D. (2018). Organizational attachment and health. Journal of Vocational Behavior, 107, 1-14. https://doi.org/10.1016/j.jvb.2018.03.003

Nunnally, J.C. (1978). Psychometric theory (2nd edn.). New York: McGraw-Hill.

Pargament, K.I., Mahoney, A., \& Shafranske, E.P. (Eds.). (2013). APA handbook of psychology, religion, and spirituality: An applied psychology of religion and spirituality (Vol. 2). Washington, DC: American Psychological Association.

Pawar, B.S. (2016). Workplace spirituality and employee well-being: An empirical examination. Employee Relations, 38(6), 975-994. https://doi.org/10.1108/ER11-2015-0215

Petchsawanga, P., \& Duchon, D. (2012). Workplace spirituality, mediation and work performance. Journal of Management, Spirituality \& Religion, 9(2), 189-208. performance. Journal of Management, Spirituatity
https://doi.org/10.1080/14766086.2012.688623

Pfeffer, J. (2010). Business and the spirit: Management practices that sustain values. In R.A. Giacalone \& C.L. Jurkiewicz (Eds.), Handbook of workplace spirituality and organisational performance (pp. 27-43). New York: M. E. Sharpe.

Prior, M.K., \& Quinn, A.S. (2012). The relationship between spirituality and social justice advocacy: Attitudes of social work students. Journal of Religion \& Spirituality in Social Work: Social Thought, 31(1-2), 172-192. https://doi.org/10. 1080/15426432.2012.647965

Redelinghuys, K., \& Rothmann, S. (2020). Exploring the prevalence of workplace flourishing amongst teachers over time. South African Journal of Industria Psychology, 45, 1-7. https://doi.org/10.4102/sajip.v46i0.1764

Rego, A., \& Cunha, M.P. (2007). Workplace spirituality and organisational commitment: An empirical study. Journal of Organisational Change Management, 21(1), 53-75. https://doi.org/10.1108/09534810810847039

Rossier, J., Ginevra, M.C., Bollmann, G., \& Nauta, L. (2017). The importance of career adaptability, career resilience, and employability in designing a successful life. In J.G. Maree (Ed.), Handbook of career adaptability, employability, and resilience (pp. 65-84). Switzerland: Springer International Publishing.

Saks, A.M. (2011). Workplace spirituality and employee engagement. Journal of Management, Spirituality and Religion, 8(4), 317-340. https://doi.org/10.1080/ 14766086.2011.630170

Savickas, M. (1997). Career adaptability: An integrative construct for life-span, lifespace theory. Career Development Quarterly, 45(3), 247-259. https://doi. org/10.1002/j.2161-0045.1997.tb00469.x

Savickas, M.L. (2013). Career construction theory and practice. In R.W. Lent \& S.D. Brown (Eds.), Career development and counseling: Putting theory and research to work (2nd edn., pp. 144-180). Hoboken, NJ: John Wiley and Sons.

Savickas, M.L. (2019). Career counselling. Washington, DC: American Psychological Association. 
Savickas, M.L., \& Porfeli, E.J. (2012). Career adapt-abilities scale: Construction, reliability, and measurement equivalence across 13 countries Journal of reliability, and measurement equivalence across 13 countries. Journal of
Vocational Behaviour, 80(3), 661-673. https://doi.org/10.1016/j.jvb.2012.01.011

Savickas, M.L., Nota, L., Rossier, J., Dauwalder, J.P., Duarte, M.E., Guichard, J., \& Van Vianen, A.E.M. (2009). Life designing: A paradigm for career construction in the 21th century. Journal of Vocational Behaviour, 75, 239-250. https://doi. org/10.1016/j.jvb.2009.04.004

Shann, C., Martin, A.J., \& Chester, A. (2014). Improving workplace mental health: A training needs analysis to inform beyondblue's online resource for leaders. Asia Pacific Journal of Human Resources, 52(3), 298-315. https://doi.org/10.1111/1744-7941.12032

Sheldrake, R. (2017). Science and spiritual practices: Transformative experiences and their effects on our bodies, brains and health. London: Hodder Stoughton.

Shibiti, R. (2019). Satisfaction with retention factors in relation to job embeddedness of public school teachers. South African Journal Human Resource Management, 17, 1-9. https://doi.org/10.4102/sajhrm.v17i0.1161

Sieberhagen, C., Rothmann, S., \& Pienaar, J. (2009). Employee health and wellness in South Africa: The role of legislation and management standards. South African Journal of Human Resources Management, 7(1), 1-9. https://doi.org/10.4102/ sajhrm.v7i1.144

Skaalvik, E.M., \& Skaalvik, S. (2017). Teacher stress and teacher self-efficacy as predictors of engagement, emotional exhaustion, and motivation to leave the

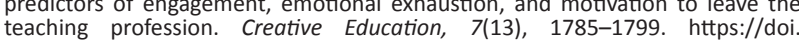
org/10.4236/ce.2016.713182

Smith, D., \& Louw, M. (2007). Conceptualisation of the spiritual life dimension: A personal and professional leadership perspective. South African Journal of Human Resource Management, 5(1), 19-27. https://doi.org/10.4102/sajhrm.v5i1.104

Tackney, C.T., Chappell, S., Harris, D., Pavlovich, K., Egel, E., Major, R., ... Stoner, J. (2017). Management, spirituality, and religion (MSR) ways and means: A paper to encourage quality research. Journal of Management Spirituality \& Religion, 14(3), 245-254. https://doi.org/10.1080/14766086.2017.1316764

Thornhill, C., \& Van Dijik, C. (2018). Public administration theory: Justification for conceptualisation. Research articles, School of Public Management and Administration (SPMA). Retrieved from http://hdl.handle.net/2263/14976
Ukanwah, C.H., \& Ndaguba, E.A. (2015). Management in achieving competitive advantage in Nigerian public organisations under the global economy. Africa's Public Service Delivery \& Performance Review, 3(3), 177-196. https://doi. org/10.4102/apsdpr.v3i3.94

Vandenabeele, W. (2008). Government calling: Public service motivation as an element in selecting government as an employer of choice. Public Administration, 86(4), 1089-1105. https://doi.org/10.1111/j.1467-9299. 2008.00728.x

Van der Walt, F., \& De Klerk., J.J. (2014). Workplace spirituality and job satisfaction. International Review of Psychiatry, 26(3), 379-389. https://doi.org/10.3109/0954 0261.2014 .908826

Van der Walt, F., \& De Klerk, J.J. (2015). The experience of spirituality in a multicultural and diverse work environment. African and Asian Studies, 14(4), 253-288. https://doi.org/10.1163/15692108-12341346

Van de Walle, S. (2010). New public management: Restoring the public trust through creating distrust? In T. Christensen \& P. Lægreid (Eds.), The Ashgate research companion to new public management (pp. 309-320). Aldershot: Ashgate.

Wang, J., Lesage, A., Schmitz, N., \& Drapeau, A. (2008). The relationship between work stress and mental disorders in men and women: Findings from a populationbased study. Journal of Epidemiology and Community Health, 62(1), 42-47. https://doi.org/10.1136/jech.2006.050591

Welthagen, C., \& Els, C. (2012). Depressed, not depressed or unsure: Prevalence and the relation to well-being across sectors in South Africa. South African Journal of Industrial Psychology, 38(1), 1-12. https://doi.org/10.4102/sajip.v38i1.984

Wu, W.Y. (1984). Clinical global impression test. Shanghai Mental Health Journal, 2, 9-21.

Zondo, R.W.D. (2018). The influence of a 360-degree performance appraisal on labour productivity in an automotive manufacturing organisation. South African Journa of Economic Management Sciences, 21(1), 1-7. https://doi.org/10.4102/sajems. v21i1.2046

Zsolnai, L., \& Flanagan, B. (2019). Routledge international handbook of spirituality in society and the professions. London: Routledge. 